\title{
JUDGE AND JURY - INCONSISTENT VERDICTS IN THE FEDERAL COURTS
}

\section{Alexander M. Bickel*}

\begin{abstract}
A PRIOR conflict among the circuit courts over whether to enter judgment of guilty on one count pursuant to a verdict which is necessarily inconsistent with a verdict of not guilty on another count was settled in 1932 by Dunn $v$. United States. ${ }^{1}$ The Supreme Court through Justice Holmes held that the verdicts should stand despite the logical impossibility they embody. The problem, one of wide implications in the administration of justice, has its setting in the body of rules which establish a division of functions between judge and jury.

In the Dunn case there was a criminal indictment in three counts: (I) for maintaining a nuisance by keeping liquor for sale; (2) for unlawfully possessing that liquor; and (3) for unlawfully selling that liquor. There were acquittals on the second and third counts but a verdict of guilty on the nuisance count. The Government's evidence, which was the same on all three counts, tended to prove that the defendant owned a place in which a sale was made of whiskey ordinarily kept underneath a bar. The defendant argued that a finding of possession was indispensable to a judgment of guilty of maintaining a nuisance, and that since the verdicts on counts (2) and (3) negatived possession, the conviction could not stand. The Court, over the vigorous dissent of Justice Butler, ${ }^{2}$ held that:
\end{abstract}

Consistency in the verdict is not necessary. . . . If separate indictments had been presented against the defendant for possession and for maintenance of a nuisance, and had been separately tried, the same evidence being offered in support of each, an acquittal on one could not be pleaded as res judicata of the other. Where the offenses are separately charged in the counts of a single indictment, the same rule must hold. ${ }^{3}$

* Law Clerk for I949-50 to Judge Calvert Magruder of United States Court of Appeals for the First Circuit. B.S.S., College of the City of New York, I947; IL.B., Harvard, I949.

${ }^{1} 284$ U.S. 390 .

$2 I d$, at 394 .

${ }^{3} I d$, at 393 . 
The appellate cases since I932 have unflinchingly followed Dunn. ${ }^{4}$ And while no case has been found reversing a trial judge, who is said to have the widest discretion in such matters, ${ }^{5}$ for granting a new trial on the sole ground that inconsistent verdicts resulted from the first one, such action by a trial court would seem to be a rare thing indeed. ${ }^{6}$

However, there is an independent and recently reaffirmed line of authority which indicates that the res judicata assumption underlying Dunn was an erroneous one. And if that assumption were the only basis of Dunn, on the theory that a defendant should not benefit from the Government's generally desirable action of joining several counts in one indictment rather than putting everyone concerned to the trouble and expense of several trials, there would be little left to say about the case except that it is plainly wrong.

For the rules of res judicata apply fully in a criminal case. ${ }^{7}$ And under those rules, if the verdict of acquittal had resulted from a supposed separate trial on the possession count in Dunn, the Government would have been foreclosed from proving possession at a later trial on the nuisance count. ${ }^{8}$ In the recent case of Sealfon $v$. United States, ${ }^{9}$ there had previously been an acquittal on a charge of conspiracy to violate sugar rationing regulations by presenting false invoices to a ration board. In the subsequent trial, the defendant was convicted on an indictment charging the substantive crime itself. The evidence was the same at both trials. The Court unanimously reversed the conviction, holding that the Government

${ }^{4}$ See, e.g., United States v. Denny, I65 F.2d 668, 670 (7th Cir. I947), cert. denied, 333 U.S. 844 (I948); Pilgreen v. United States, I57 F.2d 427 (8th Cir. 1946); Long v. United States, 90 F.2d 482 (9th Cir. r937), cert. denied, 302 U.S. 730 (I937). There are numerous other cases in which the rule of Dunn is stated, but in which no real inconsistency can be said to have existed. E.g., Allen v. United States, 89 F.2d 954, 955 (4th Cir. 1937).

${ }^{5} \mathrm{See}$ United States v. Socony Vacuum Co., 3 Io U.S. I50, 247 (I940).

${ }^{6}$ But see United States v. Kaadt, 3I F. Supp. 546, 547 (N.D. Ind. I940) ("I strongly feel that the jury should not blow both hot and cold in passing upon the rights of a defendant in a criminal indictment ..."; relying on the Butler dissent).

${ }^{7}$ United States v. Oppenheimer, 242 U.S. 85, 87 (IgI6) (Holmes, J.).

${ }^{8}$ See, e.g., United States v. De Angelo, ${ }^{3} 8$ F.2d 466 (3d Cir. I943); United States v. Clavin, 272 Fed. 985 (E.D.N.Y. I92r) ("the acquittal is res judicata for all purposes, upon every issue involved in the first indictment"). See REsTATEMIENT, JUDGMENTS $\S 68$, comments $c, m, n$ (I942). In conformance with the terminology of the Court in the Dunn case, the term "res judicata" is employed in this paper to cover both what is properly understood by that term and what may more appropriately be called an instance of collateral estoppel.

${ }^{9} 332$ U.S. 575 (1948). 
was barred from raising a second time issues of fact on which the first jury must necessarily have found for the defendant. The Sealfon case having thus conclusively underlined the error in the Dunn opinion ${ }^{10}$ it may seem that the latter case was overruled sub silentio.11

The res judicata error made in Dunn, however, should not cause that case to be overruled. For Dunn reached a result which did no more than to reaffirm the now undoubted broad powers juries won for themselves after their ancient struggles with the English judges. Viewed thus, Dunn does not conflict with Sealfon. The Court should not overrule Dunn, unless it is as disillusioned with the jury system as are some writers, ${ }^{12}$ and is willing to take a step which it will later be unable to distinguish from other radical encroachments on the jury's province.

The law states duties and liabilities in black and white terms. Human actions are frequently not as clean-cut. Judges themselves sometimes undertake, in sentencing, the search for a middle ground between the absolutes of conviction and acquittal. To deny the jury a share in this endeavor is to deny the essence of the jury's function, which is finding a solution for those occasional hard cases in which "law and justice do not coincide." 13 Dunn reaffirms the

\footnotetext{
${ }^{10}$ Of course, the entire discussion is based on the assumption of true inconsistency on the one hand, and true identity in the facts needed to support separate trial verdicts on the other. Otherwise, neither the problem in Slealfon nor that in Dunn is reached. See Pinkerton v. United States, 328 U.S. 640 (r946); United States v. Curzio, I jo F.2d 354 (3d Cir. I948). See also note 4 supra.

${ }^{11}$ It appeared, when the Court last term granted certiorari in Petti v. United States, 335 U.S. 8Ix (I948), that it might decide whether the conflict between Dunn and Sealfon was a real one. In the Petti case, a verdict of not guilty on the charge of transporting stolen securities in interstate commerce necessarily negatived the finding of an intent to transport implicit in the verdict of guilty on a count alleging a conspiracy to do so; for the only proof of the intent was the transportation itself. It was argued for Petti that the inconsistent verdicts could not stand in view of the effect of Sealfon on Dunn. But the Second Circuit held flatly that the Sealfon decision "has no application to different counts in the same indictment or to consolidated indictments." I68 F.2d 22r, 224 (2d Cir. I948). Decision was frustrated when the Court on the Government's motion remanded the case for a new trial on another issue. 336 U.S. 9r6 (I949). See Petti v. United States, Supreme Court, October Term I948, No. Ix8, Memorandum for the United States Consenting that the Judgments below be Vacated and the Cause be Remanded to the District Court for New Trial, Feb., I949.

${ }^{12}$ See Frank, Courts on Trial I08 et seq. (I949). But even as severe a critic of juries as Judge Frank has said that "as long as jury trials are guaranteed by constitutional or statutory provisions, it is the obligation of every judge, no matter what he thinks of such trials, to see . . . that the jury's province is not invaded." See United States v. Antonelli Fireworks Co., I55 F.2d 631, 642, 655 (2d Cir. I946).

${ }^{13}$ See Frank, op. cit. supra note I2, at I27-28.
} 
jury's power to exercise leniency by limiting punishment to sentence upon only one of many counts ${ }^{14}$ - even though in recognizing this power the Court alluded to it as one to which the jury has no "right." 15

Should Dunn be overruled, jurors who in the typical inconsistent verdicts case presumably believe that, in the sense of having done the act charged, the defendant is guilty, ${ }^{16}$ would be strongarmed into rendering an all-or-nothing verdict: innocent on all counts, or guilty on all. This would be accomplished through instructions more peremptory than can be obtained now; or through forced reconsideration; ${ }^{17}$ or through new trials until a jury is found which obeys instructions. Such a state of affairs would prevail until the next logical step was taken and the jury's power to acquit curtailed also. ${ }^{18}$ At present Dunn permits a sensible compromise between the necessity of convicting some likable people, or defendants who have committed a momentarily popular crime, and the tendency of juries to be reluctant to do so.

It seems likely, as was assumed by the Court, that a second jury in Dunn would have viewed the evidence on the new trial as had its predecessor, and, under strong instructions, would have convicted on all counts. By the same token, if the first jury in the Sealfon case had heard two counts rather than one indictment on a single count, it would probably have acquitted on both. At any rate, the Sealfon holding so assumes. Thus, in practical operation the two cases express the same policy: they each give the defendant the benefit of any break any single jury may wish him to have.

There are of course some reasons for changing the Dunn result which are not grounded in the desire generally to narrow the function of the jury. Thus, if Dunn should be overruled, the Govern-

14 Judges do at times, even in "hard" cases, refuse to search for the middle ground and impose stiff consecutive sentences where offenses arising out of one criminal act are charged in many counts. See 45 HARv. L. REv. 93I (I932); 4 I YALE L.J. 922 (I932) (comments on Dunn case).

${ }^{15}$ See note I6 infra.

${ }^{16}$ See Dunn v. United States, supra note $x$ at 393 , quoting from Steckler v. United States, 7 F.2d 59, 60 (2d Cir. I925): "[The inconsistency in the] verdict shows that either in the acquittal or the conviction the jury did not speak their real conclusions, but that does not show that they were not convinced of the defendant's guilt. We interpret the acquittal as no more than their assumption of a power which they had no right to exercise but to which they were disposed through lenity."

${ }^{17}$ Cf. Fed. R. Civ. P. 49.

${ }^{18} \mathrm{Cf}$. Horning v. District of Columbia, 254 U.S. I35, I39-40 (I920) (Brandeis, J., dissenting). 
ment might abandon the practice of throwing into an indictment as many as thirty-three counts, which are very frequently not necessary and can hopelessly confuse a trial; ${ }^{19}$ for the possibility of inconsistent verdicts (and, absent Dunn, of reversal) increases in direct ratio to the number of counts. Further, it may be argued that federal criminal statutes intended that the judge alone should exercise the function of sentencing. ${ }^{20}$ And in a few cases the jury's inconsistency is an unnecessary act for the judge is powerless to impose consecutive sentences anyway. ${ }^{21}$ Finally, it may be thought that inconsistency in verdicts is an unseemly phenomenon which conduces to an unhealthy popular cynicism about the administration of justice. ${ }^{22}$ However, these relatively minor considerations should not be determinative.

But the problem of Dunn may not receive its first thorough reexamination in one of the clean-cut cases in which there is a single criminal defendant. And a substantial variation, bringing into play new policy factors, develops in criminal cases where guilt is derivative and verdicts are inconsistent as they affect the master on the one hand and the servant or agent on the other. ${ }^{23}$ Or the question of Dunn v. United States may come up in a civil case.

The opponents of the jury system maintain with particular vigor that, whatever their doubtful value in criminal prosecutions,

${ }^{19}$ See, e.g., Loney v. United States, $\mathrm{I}_{5}$ I F.2d I, 4 (roth Cir. r945). But in some cases numerous counts are genuinely necessary to cover all possible phases of the evidence, and no inconsistent verdicts can result from them. See, e.g., Crichton v. United States, 92 F.2d 224 (D.C. Cir. I937), cert. denied, 302 U.S. 702 (I937).

${ }^{20}$ The judge is given discretion to impose sentence, to suspend it, to let sentences run concurrently, etc. He can impose an unexpectedly stiff sentence, and thus have the last word, even where the jury expresses a desire for leniency by its inconsistency. E.g., United States v. Porter, 96 F.2d 773 (7th Cir. 1938), cert. denied, 305 U.S. 6I2 (1938).

${ }^{21}$ This is true where, although prosecution for two offenses arising out of the same act is not prohibited by the double jeopardy clause, consecutive sentences nevertheless are, because the so-called larger offense includes all the elements of the so-called smaller one. See Ekberg v. United States, I67 F.2d 380 (Ist Cir. I948). But consecutive sentences are possible in most other cases, such as where one count charges a conspiracy to commit a crime and another charges the crime itself, since one can be guilty of either without first being guilty of the other, although it may be impossible to prove one without evidence which supports the other also.

${ }^{22}$ And yet, the apocryphal verdict, "We find the boy what stole the car not guilty, your Honor," may be "unseemly," "unlawful," but still just.

${ }^{23}$ See United States v. Dotterweich, 320 U.S. 277,279 (I943) (Dunn rule applied to verdicts that the corporation's officers were guilty and the corporation not guilty of offense committed by officers acting in corporate capacity); United States v. St. Louis Dairy Co., 79 F. Supp. I2 (E.D. Mo. I948), 62 HARv. L. Rev. 5r3 (I949) (converse facts). 
juries are certainly an outmoded encumbrance in civil trials; and it may be pointed out with force that in civil cases the courts generally exercise more control over the jury's tendency to be illogical (and yet perhaps not unreasonable) than in criminal cases. Thus, compromise verdicts are not allowed in civil suits, and where an inconsistency in the jury's verdict is brought to light by means of special interrogatories, which the jury must answer, it is not allowed to stand, and the latter control, or, if they, too, are contradictory, there is reconsideration or a new trial. ${ }^{24}$ Many states allow additurs when the jury, having found liability, awards damages which in light of the evidence are too low; but, for formal reasons which have been severely criticized, the federal courts do not. ${ }^{25}$ Again, in many states, and this time in the federal courts as well, remittiturs are given when the jury's damages appear to be too high. ${ }^{26}$ And there is not in a civil case the equivalent of a precedent such as Dunn to overrule in upsetting inconsistent verdicts. ${ }^{2 \pi}$ The argument outlined against extending the Dunn rule to civil cases is thus quite a plausible one. But it is not unanswerable.

Federal Rule 49 on special interrogatories, which by analogy presents a strong argument against Dunn, is directed at instances of confusion and manifest misapprehension by the jury of the issues, ${ }^{28}$ and not at what is a deliberate exercise by the jury of a power "to which they were disposed through lenity:" ${ }^{29}$ Compromise verdicts are distinguished in a similar way from inconsistent ones. ${ }^{30}$ The jury will render a compromise verdict, by definition, when it could not as an entity make up its collective mind on the issue of liability itself; that is, the jury is hung. Where the verdicts are inconsistent, the explanation is that the jury as a whole was convinced that liability existed, but con-

${ }^{24}$ Fed. R. Crv. P. 49.

${ }^{25}$ Dimick v. Schiedt, 293 U.S. 474 (1935) (5-4).

${ }^{26}$ See, e.g., Brooks Transp. Co. v. McCutcheon, I54 F.2d 84I (D.C. Cir. I946).

${ }^{27}$ There is a surprising dearth of authority on the force of the Dunn rule in civil suits. But there are dicta indicating approval of it. See, e.g., Jayne v. Mason and Dixon Lines, I24 F.2d 3I7, 3I9 (2d Cir. I94I). But cf. Note, Inconsistent Verdicts in Civil Trials, 45 HaRv. $\mathrm{L}$. Rev. I230 (I932) (master-servant cases in state courts).

${ }^{28}$ See, e.g., Mounger v. Wells, 30 F.2d 52 I (5th Cir. I929); see 3 Moore, Federax Practice $\$ \S 49.02,49.03$, p. 3 roo n.5 (x938).

${ }^{29}$ See note $x 6$ supra. Inconsistent verdicts are often accompanied by a recommendation of leniency. See, e.g., United States v. Albers, II5 F.2d 833 (2d Cir. I940).

${ }^{30}$ See Steckler v. United States, 7 F.2d 59, 60 (2d Cir. I925) (L. Hand, J.). 
sidered mitigating circumstances or other factors which moved it, again as a whole, not to impose the full consequences of the decision it had reached. These distinctions are not insignificant; the fundamental notion is that parties to a law suit are entitled to the true, unclouded judgment of all twelve jurymen, and that only when it is plainly evident that the verdict does not in fact embody the considered, final, and individual decisions of all twelve jurors will it be upset, other infirmities to the side.

The difference between compromise and "confused" verdicts on the one hand, and inconsistent ones on the other, is illumined by cases such as Fairmount Glass Works v. Cub Fork Coal Co. ${ }^{31}$ In this accident case the jury returned a verdict for plaintiff with damages in the amount of one dollar, although the evidence it must have believed in finding for the plaintiff showed that damages ran to $\$ 2000$ and more. The judgment entered on the verdict was affirmed, the Court stating that the jury had not compromised on a verdict, but, believing the plaintiff's story, had deliberately exercised its discretion to see to it that costs would be all he got. Justice Brandeis cited Dunn v. United States by way of analogy. It should be remembered also that additurs are in fact not granted in the federal courts.

In cases where a remittitur is appropriate, the jury, instead of treating the defendant with irrational kindness, pounces on him with undue ferocity. This is akin to a display of passion and prejudice. $^{32}$ A jury's indulgence of feelings of vindictiveness, and its exercise of leniency in the light of what it considers mitigating circumstances, are of course two quite distinct things. The one is a departure from, the other is of the essence of, the jury's role in seeing that the individual gets justice with mercy even in those special cases in which the rigid and sometimes stern (because necessarily generalized) rules provide neither.

${ }^{31} 287$ U.S. 474 (1933); Chambers v. Skelly Oil Co., 87 F.2d 853 (Ioth Cir. 1937). See also Columbia Cas. Co. v. Tibma, 63 F.2d 538 (7th Cir. I933). Cf. United States Potash Co. v. McNutt, 70 F.2d I26, I32 (Ioth Cir. I934).

${ }^{32}$ See, e.g., Brabham v. Mississippi, 96 F.2d 210, 214 (5th Cir. 1938). And note how reluctant courts are to exercise even their well-established power to upset verdicts on the ground of passion and prejudice. Cf. Houston Coca-Cola Bottling Co. v. Kelley, I3I F.2d 627, 628 (5th Cir. I942). 